\title{
The First Amendment and Compulsory Funding of Student Government Political Resolutions at State Universities
}

\author{
Donna M. Coté†
}

During the 1970s and 1980s, the student senate at the University of California at Berkeley debated and passed resolutions on such local, state, and national issues as "gay and lesbian rights, the proposed Equal Rights Amendment, gun control, the reelection of a particular United States Representative, a municipal initiative to legalize marijuana, and the treatment of political prisoners in foreign countries." Some Berkeley students disagreed with these resolutions and challenged them in court, claiming that the university infringed upon their First Amendment rights not to speak and not to associate themselves with ideas or groups they disliked. Specifically, they insisted that the university could not constitutionally use mandatory student activity fees to support a student government that passes controversial political resolutions. ${ }^{2}$

State universities use their mandatory student activity fees to fund a wide range of student services and extracurricular student groups. ${ }^{3}$ However, students, like those at Berkeley, often object to having to subsidize their student government when they disagree with the positions it takes on their behalf. ${ }^{4}$

$\dagger$ B.A. 1992, University of Virginia; J.D. Candidate 1995, The University of Chicago.

1 See Smith v Regents of University of California, 4 Cal 4th 843, 16 Cal Rptr 2d 181, 185 (1993), cert denied, 114 S Ct 181 (1993).

2 Id at 187. The First Amendment's limitations apply only to action that is "fairly attributable to the State." Lugar v Edmondson Oil Co., 457 US 922, 937 (1982). This Comment considers only First Amendment challenges to speech funded by state universities. Whether the First Amendment applies to speech funded by private universities depends on whether the private university's activities constitute "state action," id at 942, a question that falls beyond the scope of this Comment. For a discussion of what factors courts consider in determining whether private-university actions amount to state action, see Mindy A. Kaiden, Albert v. Carovano: The Second Circuit Redefines Under Color of State Law for Private Universities, 39 Am U L Rev 239 (1989); Richard Thigpen, The Application of Fourteenth Amendment Norms to Private Colleges and Universities, $11 \mathrm{~J} \mathrm{~L}$ \& Educ 171 (1982).

${ }^{3}$ See Smith, 16 Cal Rptr $2 \mathrm{~d}$ at 185.

4 See generally David Meabon, David Suddick, and Annette Gibbs, A Student Activity Fee Primer: Current Research on Collection, Control, and Allocation (National Associa- 
The Supreme Court has recognized a First Amendment right to refrain from speaking. However, it has also noted that the First Amendment's protection against forced speech and mandatory funding of speech are not absolute and sometimes give way in the face of pressing government interests. Accordingly, some university administrators have argued that their institutions' unique educational mission justifies the use of mandatory fees to fund student governments that pass political resolutions. Where this question has been litigated, university officials have insisted that such resolutions help educate participating students and spark vigorous student debate over current events and important social issues.

Although lower courts have addressed this issue, the Supreme Court has not yet decided whether a state university violates the First Amendment when it uses mandatory fees to fund a student government that passes political resolutions. ${ }^{5}$ The two state supreme courts that have considered the issue have reached opposite conclusions. ${ }^{6}$ This unresolved conflict invites further litigation.

Students have also challenged university funding of ideological and political student groups-those student organizations formed to promote a specific ideological agenda. Unlike student government, ideological and political groups such as NOW, Amnesty International, and the Young Democrats represent only a fraction of the student body. Nonetheless, lower courts have assumed that mandatory funding of ideological and political student groups presents the same First Amendment issues as mandatory funding of student government resolutions.

This Comment focuses on student government resolutions that speak for the entire student body, and concludes that funding a student government that passes political resolutions violates the First Amendment. In arriving at this conclusion, the Comment distinguishes student ideological groups that purport to speak only for their members and suggests that funding such groups is constitutional. Section I discusses the role that student government resolutions currently play at public universities.

tion for Campus Activities, 1985); David L. Meabon, Robert E. Alexander, and Katherine E. Hunter, Student Activity Fees: A Legal and National Perspective (National Entertainment and Campus Activities Association, 1979).

' On October 4, 1993, the United States Supreme Court denied California's petition for certiorari in the Smith case. Regents of University of California $v$ Smith, $114 \mathrm{~S} \mathrm{Ct} 181$ (1993).

${ }^{6}$ See Section III. 
Section II reviews the First Amendment case law that recognizes a right not to speak or fund speech. Section III summarizes the two state supreme court cases addressing First Amendment challenges to mandatory funding of student government political resolutions. Finally, Section IV concludes that the First Amendment prevents a state university from forcing a student to fund a student government that purports to make political statements on her behalf.

\section{The Nature of the Problem}

In 1965, when President Johnson underwent gall bladder surgery, the student council at Georgetown University considered a resolution to send him a get-well card. After some debate, the resolution was rejected as partisan and inherently beyond the purview of the student council, supposedly an impartial representative assembly. ${ }^{7}$ As then-Georgetown-student Bill Clinton wrote in his race for student council president two years later, "[t]he student council is the instrument of the students, it is NOT a debating society or a forum for hollow resolutions."

Often, however, student governments fail to exercise such restraint. Instead, they pass resolutions that purport to speak for the entire student body and advocate particular viewpoints on divisive political issues. These resolutions very rarely reflect a uniformity of opinion within the student body. Recent examples illustrate these points.

Several student governments have passed resolutions challenging government policy toward homosexuals. For example, the student government at the University of Washington ("UW") passed a resolution condemning the military's refusal to commission homosexual ROTC members as officers. ${ }^{9}$ The resolution also urged the UW Board of Regents and administrators to pressure Congress to change the military's policy. Many students opposed the resolution, insisting that the presence of homosexual officers would adversely affect, among other things, the ability of the armed forces to maintain discipline and morale and to "facilitate assignment and worldwide deployment of members who frequent-

7 Dick Williams, Clinton's College Life, Atlanta Const F1 (Oct 4, 1992).

8 Bill Clinton, Young President Clinton, NY Times A17 (Dec 21, 1992) (reprinting excerpts from Bill Clinton's campaign pamphlet in his 1967 race for Georgetown University student council president).

9 Sally MacDonald, Ban on Homosexual ROTC Officers Protested by Students, Seattle Times A5 (May 5, 1990). 
ly must live and work under close conditions affording minimal privacy." $" 10$

Student governments have not limited their review of government policy to its treatment of homosexuals. In fact, no political issue has proved immune from scrutiny. ${ }^{11}$ For example, the Persian Gulf War inspired the University of Montana student senate to pass a resolution opposing $i t^{12}$ and the University of Alabama student government to pass a resolution supporting the troops and the war. ${ }^{13}$ Neither resolution reflected the sentiment of the entire student body. At Montana, the more common student reaction to the war was not antagonism but rather "bafflement, concern, and ambivalence."14 Some campus student groups affirmatively rallied in support of the war effort, showing their disagreement with the student senate resolution. ${ }^{15}$ Likewise, the Alabama resolution did not meet with general support from the student body. Indeed, in an effort to defuse mounting tension, University of Alabama administrators called a special forum at which students could vent their opposing viewpoints over the war in a neutral setting. ${ }^{16}$

Student governments have also passed resolutions on a host of other social issues. For instance, at Texas A\&M the student senate passed a resolution condemning "cultural insensitivity. ${ }^{17}$ This resolution, coming in close temporal proximity with the university's decision to add a multicultural requirement to the

$10 \mathrm{Id}$.

"For example, the student senate at Eastern Kentucky University passed a resolution challenging the United States Army's plan to incinerate chemical weapons. Keith Schneider, U.S. Plan to Burn Chemical Weapons Stirs Public Fear, NY Times A1, A12 (Apr 29, 1991). In addition, student senates at the Lewis-Clark State College and University of Idaho have passed numerous resolutions opposing pending state legislation that would reduce state funding for institutions of higher learning. LCSC Students Aid Foes of 1\% Initiative, Lewiston Morning Trib 8A (Oct 21, 1992) (Lewis-Clark State College); Michael R. Wickline, 1 Percent Initiative: 'The Options Aren't Pretty': Higher Education Institutions in Idaho Warn of Big Cutbacks, Lewiston Morning Trib 8A (Oct 26, 1992) (University of Idaho).

12 Barbara Reynolds, War on Campus: Debate Over Gulf War Reawakens Activism, USA Today 11A (Feb 7, 1991) (interview with Todd Gitlin, a UC Berkeley sociologist and former Vietnam protester); Todd Gitlin, Student Activism Without Barricades, LA Times M1 (Dec 23, 1990).

${ }^{13}$ S. Shyam Sundar, The Persian Gulf War-The Student Front at Alabama, LA Times M4 (Jan 27, 1991).

14 Gitlin, LA Times at M1.

$15 \mathrm{Id}$.

16 Sundar, LA Times at M4.

17 Linda Stewart, A\&M Shoved into Debate over Multicultural Courses, Dallas Morning News 47A (July 4, 1993). 
mandatory student core curriculum, was part of a heated debate during which the University Republicans called upon alumni to withhold contributions in protest of such "politically correct indoctrination." 18

Similarly, at Tufts University, a controversial speaker inspired a student senate resolution condemning the Nation of Islam for holding Jews responsible for apartheid. ${ }^{19}$ However, the student body was sharply divided on this issue. One freshman wrote in a campus newspaper editorial, "For all of you white/Jewish students who opposed [condemning Jews for apartheid], the truth hurts, now, lick your wounds and deal with it." As a Tufts rabbi commented, "In my 13 years at Tufts, I can't remember feeling quite so much anger and tension between black and Jewish students."21

At Douglass College, the student government passed a resolution condemning pornography and recommending that three magazines and a greeting card that the student government considered pornographic be removed from the campus store. ${ }^{22}$ Many female and male students hotly disagreed with the resolution. One senior noted: "Pornography is part of our culture; we are not changing the issue by removing the magazines. ${ }^{23}$ In the uproar over the resolution, sales of the three magazines doubled and the greeting cards sold out. ${ }^{24}$

As these few examples indicate, a significant number of university students often disagree with the diverse and controversial resolutions passed by their student governments. Others would prefer not to take a public position on these issues at all. When a university uses mandatory student activity fees to fund political resolutions, however, these dissenters are compelled to support the political positions endorsed by the majority.

\section{FIRST AMENDMENT COMPELLED SPEECH DOCTRINE}

Students dissatisfied with their student governments' political resolutions have challenged the validity of such resolutions in court. Specifically, some student-plaintiffs have alleged that state

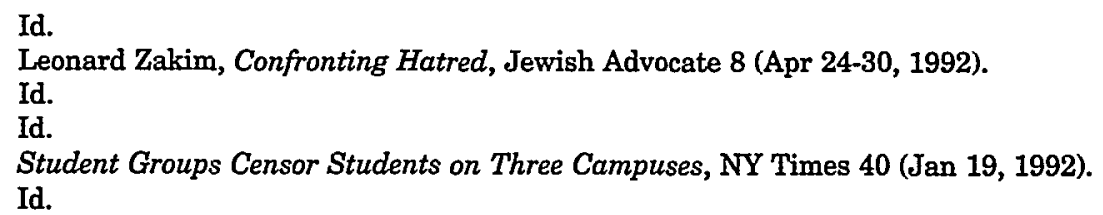


universities violate their First Amendment rights to refrain from speaking or from funding political speech when the schools use mandatory fees to fund a student government that passes political resolutions.

This Section will first explore the Supreme Court's treatment of the First Amendment right to refrain from speaking when this right conflicts with pressing government interests. It next addresses the way in which lower courts have dealt with First Amendment challenges to a university's use of mandatory student fees to fund political or ideological student groups such as NOW, Amnesty International, and the Young Democrats.

\section{A. The Right to Refrain from Speaking}

In West Virginia Board of Education v Barnette, the Supreme Court recognized that the First Amendment's Free Speech Clause protects the right to be free from compelled speech and association. ${ }^{25}$ In Barnette, the Supreme Court struck down a West Virginia law that compelled public school students to pledge allegiance to the United States flag. Writing for the Court, Justice Jackson recognized that the First Amendment protects not just an individual's right to speak freely, but the concomitant right to refrain from speaking at all:

If there is any fixed star in our constitutional constellation, it is that no official, high or petty, can prescribe what shall be orthodox in politics, nationalism, religion, or other matters of opinion or force citizens to confess by word or act their faith therein. ${ }^{26}$

The Supreme Court has extended the right to refrain from speaking to include the right of an individual to abstain from funding political speech with which she disagrees. ${ }^{27}$ In Abood $v$

25319 US 624, 642 (1943). The First Amendment protects freedom of association, and "therefore plainly presupposes a freedom not to associate." Roberts $v$ United States Jaycees, 468 US 609,623 (1984) (holding that a Minnesota law requiring the United States Jaycees to admit women did not abridge male members' freedom of association). Similarly, the Supreme Court has held that the First Amendment right to speak implies a corresponding right to "refrain from speaking." Wooley v Maynard, 430 US 705, 714 (1977) (invalidating a New Hampshire law compelling drivers to endorse the motto "Live Free or Die" on their license plates).

${ }_{26} 319$ US at 642 . The right not to speak or associate allows an individual to determine for herself what identity or personality she will present to the world. "A system which secures the right to proselytize religious, political and ideological causes must also guarantee the concomitant right to decline to foster such concepts." Wooley, 430 US at 714.

27 The Court has applied the right to refrain from speaking in a variety of settings. 
Detroit Board of Education, nonunion teachers challenged Michigan's agency shop rules, which compelled them to pay a service charge to the union that negotiated their collective bargaining agreement. ${ }^{28}$ The nonunion teachers disapproved of the union's use of the service charge to fund a variety of "economic, political, professional, scientific and religious" activites that were unrelated to collective bargaining. ${ }^{29}$ They argued that compelling them to fund these activities violated the First Amendment. $^{30}$

The Court held that while the union could use the mandatory dues to finance political activities germane to collective bargaining, it could not use them to finance political or ideological causes unrelated to collective bargaining without violating the First Amendment. ${ }^{31}$ According to the Court, "[t]he fact that [employees] are compelled to make... contributions for political purposes works ... [as] an infringement of their constitutional rights." ${ }^{32}$ The Court acknowledged Thomas Jefferson's view that "to compel a man to furnish contributions of money for the propagation of opinions which he disbelieves[ ] is sinful and tyrannical. ${ }^{33}$ Accordingly, the Court reversed the lower court's denial of relief and remanded to provide the plaintiff-teachers with the

See, for example, Torcaso $v$ Watkins, 367 US 488, 496 (1961) (striking down as invasive of "freedom of belief and religion" a Maryland requirement that civil servants utter oaths affirming belief in God); Miami Herald Publishing Co. $v$ Tornillo, 418 US 241, 255-56 (1974) (holding that a newspaper could not be compelled to print a reply by a political candidate criticized in the paper); Elrod $v$ Burns, 427 US 347, 356 (1976) (holding that sheriff's employees could not be compelled to support a political party in order to keep their jobs); Pacific Gas \& Electric Co. v Public Utilities Comm'n of California, 475 US 1, 10-11 (1986) (overturning a utility commission's rule requiring a company to distribute a consumer organization's communications with its bill).

${ }^{23} 431$ US 209, 212-13 (1977). "A union that obtains the support of a majority of employees in the appropriate bargaining unit is designated the exclusive representative of those employees. A union so designated is under a duty of fair representation to all employees in the unit, whether or not [they are] union members." Id at 223-24 (citations omitted). In an agency shop, every employee represented by a union, whether or not a member of that union, must pay a service charge to the union. This requirement insures that all employees contribute to their exclusive bargaining representative and prevents nonmember employees from free riding on the efforts of union members. Id at 221-22.

29 Id at 213. The plaintiff-teachers did not describe the nature of these activities in any further detail. Id at $213 \mathrm{n} 3$.

30 Id at 213 .

31 Id at $235-36$.

32 Id at 234. The Court further noted that "at the heart of the First Amendment is the notion that an individual should be free to believe as he will, and that in a free society one's beliefs should be shaped by his mind and his conscience rather than coerced by the State." Id at 234-35.

33 Id at $235 \mathrm{n}$ 31, quoting Thomas Jefferson, as quoted in Irving Brant, James Madison: The Nationalist 1780-1787 354 (Bobbs-Merrill, 1948). 
opportunity to prove the allegations set forth in their complaint. $^{34}$

However, the Abood Court also indicated that First Amendment protections are not absolute in a mandatory-fee context. It concluded that the nonunion teachers could be compelled to support the union financially in order to advance the state's compelling interest in promoting labor peace. ${ }^{35}$ Thus, Michigan's agency shop rules did not violate the First Amendment so long as the mandatory dues were not used to pay for political speech unrelated to the union's role as collective bargaining agent. ${ }^{36}$

The Supreme Court applied the same reasoning to strike down the political activities of an integrated state bar association. ${ }^{37}$ In Keller $v$ State Bar of California, the Court held that the California Bar's use of compulsory dues to fund an annual conference of delegates that passed political resolutions endorsing gun control and a nuclear freeze initiative was unconstitutional. ${ }^{38}$ The Court concluded that these expenditures violated the First Amendment rights of members who objected to the resolutions because such expenditures were "not necessarily or reasonably incurred for the purpose of regulating the legal profession or improving the quality of legal services. ${ }^{m 9}$

${ }^{34} 431$ US at $241-42$.

${ }_{35}$ Id at 234-37.

${ }^{36}$ Id. The Supreme Court noted that the union could not avoid the First Amendment problem simply by applying dissenters' monies only to apolitical union expenses. Because this shifting of funds leaves the same total amount of money at the organization's disposal and permits the organization to spend the same amount on political activities, earmarking "is of bookkeeping significance only rather than a matter of real substance." Id at $237 \mathbf{n}$ 35, quoting Retail Clerks Local $1625 v$ Schermerhorn, 373 US 746, 753 (1963).

${ }_{37}$ In an "integrated bar," membership and dues are required as a condition of practicing law in that state.

${ }^{33} 496$ US 1, 16 (1990). Petitioners' complaint alleged that the conference of delegates funded and sponsored by the California Bar endorsed a gun control initiative, disapproved statements of a United States Senate candidate regarding court review of a victim's bill of rights, endorsed a nuclear freeze initiative, and opposed federal legislation limiting federal court jurisdiction over abortions, public school prayer, and busing. Id at 6 n 2.

For in-depth analyses of Keller, see Note, Renovating the Bar after Keller v. State Bar of California: A Proposal for Strict Limits on Compulsory Fee Expenditures, 25 USF L Rev 681, 711-16 (1991) (arguing bar should limit dues expenditures to only those necessarily or reasonably related to its function of regulating the legal profession); Note, Keller v. State Bar of California: Freedom From Ideological Association for Members of Integrated Bar Associations, 35 SLU L J 903, 923-29 (1991) (predicting that state bar associations will develop procedures through which members who have funding objections may air their grievances); Casenote, Constitutional Law-First Amendment-Compulsory State Bar Associations: Keller v. State Bar of California, 68 U Detroit L Rev 297, 304 (1991) (contending that courts will soon develop criteria for evaluating "the constitutional permissibility of a wide range of political and ideological programs," thereby nullifying the initial caution and confusion created by Keller).

39496 US at 15-16. Previously, in Lathrop v Donohue, 367 US 820 (1961), the Su- 
Recently, in Lehnert $v$ Ferris Faculty Ass'n, the Court provided greater guidance as to when a union can spend compulsory dues on political speech. ${ }^{40}$ In Lehnert, the Court held that, in order to be constitutional, the use of dissenters' dues for political activity must be "germane to collective bargaining," must be "justified by the government's vital policy interest in preserving peace and eliminating free riders, ${ }^{31}$ and must not significantly add to the First Amendment burden inherent in compelling all workers to pay dues to the union that represents them. ${ }^{42}$

In Lehnert, the Court held that under this three-prong test the union had only limited power to fund political activities with mandatory dues. Justice Blackmun stated that the plaintiffs could not be compelled to subsidize public relations activities because the activities were "not sufficiently related" to the union's collective bargaining function even though these activities might have enhanced the reputation of the teaching profession and improved the union's bargaining position. ${ }^{43}$ Similarly, Blackmun concluded that the union could require dissenters to pay for only those lobbying activities within "the limited context of contract ratification or implementation." 44 The union could not compel the plaintiffs to subsidize lobbying on other issues, even those as closely related to the union's interests as taxes for the support of public education. ${ }^{45}$

preme Court had rejected a lawyer's challenge to a state bar requirement that he join and pay dues to an integrated state bar association. However, in a split decision, the Lathrop court decided not to address the issue of whether lawyers' free speech rights were infringed when their dues were used by the bar to finance political activities with which they disagreed. Id at 845 .

400 US 507, 519-22 (1991). For a look at how courts have applied Lehnert in the union-dues context, see Note, Defining the Permissible Uses of Objecting Members' Agency Dues: Is the Solution Any Clearer After Lehnert v. Ferris Faculty Ass'n?, 70 U Detroit Mercy L Rev 89, 122-23 (1992) (arguing that more deference should be accorded union lobbying and public relations activities as these are reasonably designed to influence public employees' position at the bargaining table); Note, Respecting Nonunion Member Employees' Rights While Avoiding a Free Ride, Lehnert v. Ferris Faculty Association, 10 Hofstra Labor L J 349, 363-73 (1992) (concluding that Lehnert provides a clearer understanding of what is chargeable to nonmember employees).

11 "Free riders" refers to those nonunion members who, by not paying a service charge to the union, would unfairly piggyback on the collective bargaining efforts of union members. See $A b o o d, 431$ US at 221-22.

42500 US at 519.

43 Id at 528. Parts of Blackmun's opinion in this case delivered the opinion of the Court, but some parts of his opinion were joined only by Chief Justice Rehnquist and Justices White and Stevens. The latter parts will hereafter be referred to collectively as the "Blackmun opinion."

4 Id at 522 (Blackmun opinion).

45 Id at 527 (Blackmun opinion). 
The Supreme Court has therefore invalidated compulsory funding of political speech where that speech was not "sufficiently related" to the function of the union or bar. In Abood, Keller, and Lehnert, the Court required a close fit between political speech that may be constitutionally funded and the union's or bar's mission.

\section{B. The Funding of Ideological and Political Student Groups}

While most student groups are devoted to academic, cultural, or recreational pursuits, ${ }^{46}$ other groups like NOW, Amnesty International, and partisan organizations like the Young Democrats and Young Republicans pursue ideological or political goals. ${ }^{47}$ Some students have challenged their universities' use of mandatory fees to fund these groups. ${ }^{48}$ Reviewing the case law ad-

46 The physics club, the Spanish club, and the ski club are a few typical examples.

47 A detailed examination of the constitutionality of the funding of political student groups is beyond the scope of this Comment. For an exhaustive treatment of the constitutionality of such funding, see generally Norman L. Cantor, Forced Payments to Service Institutions and Constitutional Interests in Ideological Non-Association, 36 Rutgers $L$ Rev 3, 51-52 (1983) (concluding that First Amendment constitutional concerns are satisfied by neutral funding allocation); Charles Thomas Steele, Jr., Mandatory Student Fees at Public Universities: Bringing the First Amendment Within the Campus Gate, $13 \mathrm{~J}$ Coll \& Univ L 353,374 (1987) (concluding that only funding of organizations that are "essentially partisan and noneducational in nature" infringes upon First Amendment rights); Recent Developments, Constitutional Law: The First Amendment and Compulsory Funding of Political Advocacy-Galda v. Rutgers, 772 F.2d 1060 (1985), 9 Harv J L \& Pub Policy 731, 735-36 (1986) (arguing that unless many voices are speaking in the forum, people should not be forced to subsidize those who are); Note, The Constitutionality of Student Fees for Political Student Groups in the Campus Public Forum: Galda v. Bloustein and the Right to Associate, 15 Rutgers L J 135, 179-84 (1983) (reasoning that university funding of political student groups with mandatory fees does not violate the First Amendment so long as funds are distributed in a neutral manner and can be refunded upon request); Comment, "Fee Speech": First Amendment Limitations on Student Fee Expenditures, 20 Cal W L Rev 279, 309-11 (1984) (concluding that university funding is permissible as long as there is a forum to which dissenters have access or dissenters have the option to withhold funds); Comment, Who Should Speak? Who Should Pay? The Complexities of Refunding Student Fees at Public Colleges and Universities, 11 J Coll \& Univ L 481, 49599 (1985) (emphasizing need to consider nature of fee, manner and motivation behind proposed refund, and ethical consequences of refund policy); Comment, Mandatory Student Fees: First Amendment Concerns and University Discretion, 55 U Chi L Rev 363, 395 (1988) (arguing that critical question for determining constitutionality is whether program allows all organizations "to compete for funds on an equal footing"); Note, A Funny Thing Happens When You Pay for a Forum: Mandatory Student Fees To Support Political Speech at Public Universities, 103 Yale L J 2009, 2021-38 (1994) (applying the public forum doctrine to state universities and concluding that university officials cannot discriminate against political groups).

48 The question of funding for ideological student groups has been litigated in a number of settings. See, for example, Smith $v$ Regents of University of California, $4 \mathrm{Cal}$ 4th 843, 16 Cal Rptr 2d 181, 187-95 (1993), cert denied, 114 S Ct 181 (1993) (regarding 
dressing this controversy sheds light on the issues surrounding the funding of student government political resolutions. ${ }^{49}$

In Carroll $v$ Blinken, the Second Circuit upheld the State University of New York's use of mandatory fees to support an ideological student group. ${ }^{50}$ According to the court, the funding promoted "a substantial government interest that would thave been] achieved less effectively absent the regulation" allocating the activity fees. ${ }^{51}$ The court, relying on Abood, conceded that the student-plaintiffs had a viable First Amendment right not to fund ideological speech. ${ }^{52}$ Nonetheless, the court upheld the university's decision to fund the group with mandatory fees, holding that the university's interests in providing a rich extracurricular environment, educating students, and creating a diverse forum for the expression of controversial ideas could not be

student objections to funding of fourteen politically active student groups, including Campus NOW and Campus Abortion Rights Action League); Hays County Guardian $v$ Supple, 969 F2d 111 (5th Cir 1992), cert denied, 113 S Ct 1067 (1993) (regarding student objections to funding of a university newspaper); Carroll $v$ Blinken, 957 F2d 991 (2d Cir 1992) (concerning student objections to funding of NYPIRG, a public interest group with a liberal, progressive political agenda); Galda v Rutgers, 772 F2d 1060 (3d Cir 1985) (addressing student objections to a separate mandatory fee to support the New Jersey PIRG, a political advocacy group); Kania $v$ Fordham, 702 F2d 475 (4th Cir 1983) (concerning student objections to funding of school newspaper that printed controversial editorials); Arrington v Taylor, 380 F Supp 1348 (M D NC 1974) (regarding student objections to funding of school newspaper); Veed v Schwartzkopf, 353 F Supp 149 (D Neb 1973), aff'd, 478 F2d 1407 (8th Cir 1973) (regarding student objections to funding of school newspaper, student association, and speaker series); Larson $v$ Board of Regents of University of Nebraska, $189 \mathrm{Neb} 688,204$ NW2d 568 (1973) (concerning student objections to funding of student newspaper and speaker series); Lace $v$ University of Vermont, 131 Vt 170, 303 A2d 475 (1973) (regarding student objections to funding of speaker series, student newspaper, and film series).

49 Student government speech can and should be distinguished from speech promulgated by ideological and political student groups. First, while there can be an infinite number of political and ideological student groups in the university community, each equally able to speak in opposition to views espoused by other groups, there is but one student government, which claims to represent everyone. Second, while personal association with political and ideological groups is voluntary, all students are necessarily viewed as "affiliated" with the student government. Third, while these voluntary groups speak on behalf of only their members, the student government speaks for the entire, diverse student body. The student government and political or ideological groups thus present distinct constitutional questions, each meriting a separate though related constitutional analysis. Despite these distinctions, however, several important general principles that emerge from the ideological-student-group cases apply to student government resolutions as well.

so 957 F2d 991, 1003 (2d Cir 1992).

${ }^{51}$ Id at 999, quoting United States $v$ Albertini, 472 US 675, 689 (1985).

62957 F2d at 997 ( $\mathrm{A}$ A student cannot pay the full fee without paying [the ideological group] and he or she cannot continue as a student without paying the full fee. Whether justified or not, that is forced association and speech . ...."). 
achieved through any means less restrictive of First Amendment freedoms. ${ }^{53}$

However, the Carroll court rejected the ideological group's automatic-membership policy, by which the group purported to speak on political issues on behalf of the entire student body. ${ }^{54}$ While the court was willing to uphold the university's use of mandatory student fees to support the group where it was just one among a myriad of other diverse student groups engaged in political speech, the court would not allow the university to fund the group where the group had an unfair advantage over the other student groups. As the court noted:

Far from fulfilling SUNY Albany's interest in promoting campus pluralism and free choice among several avenues of informal learning, allowing one group to make members of all students gives it an unearned advantage in the campus competition for hearts and minds.... By ... claiming to represent the interests of the [entire] student body, [the group] has irredeemably transgressed the proscription against forced association.... [The group's] membership provision amounts to special treatment that skews the university's otherwise neutral support of a variety of viewpoints. ${ }^{55}$

The Carroll court's analysis suggests that a university may not fund a student government, which by definition speaks on behalf of the entire student body, that passes political resolutions. Because student government has a special advantage that follows from students' mandatory association, such funding would not enhance a "balance in access" for all student groups. To the contrary, in subsidizing the political speech of a student government, a university would be damaging the diverse forum of ideas it is so eager to protect and cultivate.

By contrast, in Smith $v$ Regents of University of California the California Supreme Court ruled that the University of California at Berkeley's use of mandatory student fees to fund political student groups violated the First Amendment. ${ }^{57}$ The court,

53 Id at 1001-02.

54 Id at 1003 .

65 Id (emphasis added).

56 Id, quoting Galda, 772 F2d at 1067.

574 Cal 4th 843, 16 Cal Rptr 2d 181, 198 (1993), cert denied, 114 S Ct 181 (1993). The Smith court was presented with constitutional challenges both to the funding of ideological and political student groups and to the funding of the Berkeley student govern- 
relying on Abood, Keller, and Lehnert, applied a strict scrutiny test. ${ }^{58}$ Declaring that "a group's dedication to achieving its political or ideological goals, at some point, begins to outweigh any legitimate claim it may have to be educating students on the University's behalf,"59 the court concluded that the use of mandatory fees to fund political student groups could not be justified. ${ }^{60}$ In short, the court concluded that means less restrictive of students' First Amendment freedoms existed for the university to achieve its educational interests. ${ }^{61}$

Likewise, in Galda $v$ Rutgers, the Third Circuit found that Rutgers University's funding of a nonprofit statewide ideological student organization with a mandatory student assessment violated the First Amendment. ${ }^{62}$ The court found that the organization functioned essentially as a political action group with only an incidental educational component. ${ }^{63}$ The court applied the Supreme Court's analysis in the union dues cases, declaring, "[i]n short, what Abood holds objectionable is the 'compulsory subsidization of ideological activity' by those who object to it." court concluded that the university failed to show that any "compelling state interest" justified the imposition of a separate mandatory fee to support a group "dedicated to advancing one position" when alternatives less restrictive of student rights could have provided the same educational benefits to participating students. ${ }^{65}$

In sum, the lower court cases dealing with mandatory funding of ideological student groups illustrate a number of important points for this Comment's analysis of student government politi-

ment that passed political resolutions. This Section of the Comment addresses the part of the Smith court's decision dealing with the funding of ideological and political groups as a prelude to a discussion of Smith's treatment of student government political resolutions in Section III.B.

58 16 Cal Rptr 2d at 189.

59 Id.

कs Id at 194.

61 Id.

62772 F2d 1060, 1068 (3d Cir 1985).

63 Id at 1065. In Galda, the court was presented with the university's assessment and use of a segregated fee earmarked specifically for the organization in question. The court explicitly stated that it did not need to extend its analysis to the situation presented by use of the general student activity fee to fund controversial student groups. Id at 1064 . Nonetheless, the Galda court's analysis sheds light on the First Amendment implications of using mandatory student fees to fund ideological student groups.

${ }^{64}$ Id at 1064, quoting $A b o o d, 431$ US at 237.

65772 F2d at 1067. The court contrasted this use of a mandatory fee with a union's use of dissenters' dues, which could be justified by the state's compelling interest in promoting labor peace and avoiding a free-rider problem. Id at 1066-67. 
cal resolutions. First, these courts recognize that a university's use of mandatory student fees creates a First Amendment burden on those fee-paying students who object to the funded speech. Second, the courts have extended the Supreme Court's union dues and integrated bar analysis to the context of state universities' use of mandatory fees, finding such precedent the appropriate source of law on which to draw. ${ }^{66}$ Third, although they do not specifically address the funding of student government resolutions, these cases demonstrate that a university's use of mandatory fees to fund student groups becomes more problematic as the number of viewpoints funded in the university community decreases, or as any one student group engaged in political speech enjoys an unfair advantage vis-à-vis other student groups.

\section{THE CURRENT STATE OF THE CONTROVERSY OVER FundING STUDENT GOVERNMENT POLITICAL RESOLUTIONS}

So far, the only two courts confronted with First Amendment challenges to mandatory funding of student government political resolutions have reached opposite conclusions. This Section examines the virtues and shortcomings of both approaches.

\section{A. The Good Approach: Funding Is Constitutional}

In Good $v$ Associated Students of University of Washington, the Washington Supreme Court upheld the University of Washington's use of mandatory dues to subsidize political resolutions passed by the student senate. ${ }^{67}$ The Good court found that student government resolutions contributed to the university's forum of ideas by fostering debate on important social issues. ${ }^{68}$

6s See Carroll, 957 F2d at 996-98; Smith, 16 Cal Rptr 2d at 187-98; Galda, 772 F2d at $1063-64$.

6786 Wash 2d 94, 542 P2d 762, $769-70$ (1975).

${ }^{63}$ Id at 768-69. Good, like many ideological-student-group cases, relies on the identity of a public university as a public forum to support its analysis. See Hays County Guardian v Supple, 969 F2d 111, 116-17 (5th Cir 1992), cert denied, 113 S Ct 1067 (1993) (holding that a public university campus is a "designated" public forum). As a public forum, a university assumes a special status; it must allow access to all who wish to speak, though it may exclude those groups who would disrupt the educational environment. See, for example, Widmar $v$ Vincent, 454 US 263 (1981) (religious group could not be denied access to university facilities). Courts like the Good court have upheld the use of mandatory student fees to support a controversial group, reasoning that the complaining students' mandatory fees actually support a forum created by the diverse student groups taken as a whole rather than any one particular group. See, for example, Arrington $v$ Taylor, 380 F Supp 1348, 1362 (M D NC 1974) (noting that the university 
The court held that the university's traditional interest in providing an atmosphere of learning and debate outweighed the students' First Amendment rights as long as the student senate did not "become the vehicle for the promotion of one particular viewpoint ...." ${ }^{\prime 69}$ The court remanded the case for a determination of whether the student senate had an impermissible ideological bias. ${ }^{70}$

Good's analysis is flawed in several critical respects. First, in order to assure that it was not funding a student government that consistently promoted one ideology, a university would have to examine the political viewpoints of the student government's resolutions as they were passed. ${ }^{71}$ However, the Supreme Court has clearly indicated that the government may not base funding decisions on the ideological viewpoint of speech under consideration.

In Regan $v$ Taxation with Representation of Washington, the Supreme Court upheld legislation that denied a certain group a tax preference. ${ }^{72}$ Congress denied the preference because the group planned to engage in substantial political lobbying. The Court held that while Congress cannot penalize organizations for

newspaper does not speak on behalf of any particular group, but instead provides a forum whereby diverse views on controversial subjects may be presented); Veed v Schwartzkopf, 353 F Supp 149, 152 (D Neb 1973), aff'd, 478 F2d 1407 (8th Cir 1973) (concluding that university may use mandatory fees to provide forum for the expression of political and personal opinions so long as the forum does not discriminate against any particular viewpoint); Lace $v$ University of Vermont, $131 \mathrm{Vt} 170,303 \mathrm{A2d} 475,479-80$ (1973) (holding that mandatory funding of forum contributes to the "marketplace of ideas" and is permissible so long as equal and proportionate access is assured). See also Note, 103 Yale $\mathrm{L} J$ at 2038 (cited in note 47) (concluding that public forum doctrine prohibits denial of equal access to political groups). This Comment suggests that the argument that the funds create a forum for debate is inapposite where a university uses mandatory fees to support student government, the exclusive mouthpiece of the student body. Viewpoint-based arguments are red herrings; rather, the focus should be on the compelled speech doctrine. Thus, the fact that there is some debate before the passage of a resolution is irrelevant because some students will still find their funds being used to espouse views with which they disagree.

$642 \mathrm{P} 2 \mathrm{~d}$ at 769.

7o Id at 770 .

71 This approach is not unique. In Larson $v$ Board of Regents of University of Nebras$k a, 189$ Neb 688, 204 NW2d 568 (1973), a group of students objected to the university's use of mandatory student fees to fund a school newspaper and a speakers' program. The Larson court imposed a duty on the university to make sure that "such a newspaper ... not be allowed to become a vehicle for expressing a single political point of view." Id at 571. The Good court, treating student government as any other student group engaged in political speech, relied on this analysis, holding that a student government could pass political resolutions as long as it did not become the vehicle for any particular ideology. 542 P2d at 769.

${ }^{72} 461$ US 540, 545-46 (1983). 
exercising their First Amendment speech rights through lobbying, Congress is under no constitutional obligation to subsidize them with public funds. ${ }^{73}$ However, the Court indicated that Congress may refuse to subsidize speech only if in doing so it does not "discriminate invidiously" against a certain viewpoint. ${ }^{74}$ Thus, if the legislation had denied the group a tax preference based on the particular viewpoint the group expressed through lobbying (against federal tax laws) while allowing a tax preference for similar lobbying groups based on their viewpoint (in support of federal tax laws), the legislation would have been disallowed.

Analogously, a public university may not consider the ideological viewpoint of a student government political resolution when deciding whether to fund it, as Good's solution would require. ${ }^{75} \mathrm{~A}$ state cannot justify viewpoint discrimination as an attempt to correct for an existing ideological imbalance.

Even if a university, consistent with the First Amendment, could use its funding decisions to adjust the ideological tenor of its student government, two problems with the Good court's solution remain. First, the ideological-balancing inquiry begs the central constitutional question that student government political resolutions present. In promoting such a test, the Good court did

73 Id. "Although [the group at issue] does not have as much money as it wants, and thus cannot exercise its freedom of speech as much as it would like, the Constitution 'does not confer an entitlement to such funds as may be necessary to realize all the advantages of that freedom." Id at 550, quoting Harris $v$ McRae, 448 US 297, 318 (1980). Thus, while the state may not interfere with valid First Amendment rights, it does not have to subsidize the exercise of those rights. See also Lyng $v$ Automobile Workers, 485 US 360 (1988) (upholding a federal statute that made strikers ineligible for food stamps); Regan, 461 US at 545 (holding that Congress need not "grant a benefit . . . to a person who wishes to exercise a constitutional right"); Harris, 448 US at 316 ("AA]lthough government may not place obstacles in the path of a [person's] exercise of [a constitutional right], it need not remove those not of its own creation."); Maher $v$ Roe, 432 US 464, 479-80 (1977) (holding that state may refuse to fund abortions that are not medically necessary); Cammarano $v$ United States, 358 US 498, 513 (1959) (holding that income tax deductions are not required for funds expended on lobbying).

74461 US at 548.

75 For a thorough explanation of the Regan doctrine and the concept of viewpoint discrimination in subsidy cases, see Comment, University Regulation of Student Speech: Considering Content-Based Criteria Under Public Forum and Subsidy Doctrines, $1991 \mathrm{U}$ Chi Legal F 393, 399-401 (arguing that viewpoint discrimination in university funding of student groups is more problematic than content discrimination under the First Amendment because it expresses state bias); Note, 103 Yale $\mathrm{L} J$ at 2030-38 (cited in note 47) (concluding that viewpoint discrimination by university officials is particularly egregious in light of the public forum doctrine). See also Geoffrey R. Stone, Content Regulation and the First Amendment, 25 Wm \& Mary L Rev 189, 234-51 (1983) (arguing for close scrutiny of viewpoint-based restrictions). 
not consider the compelled speech problem inherent even in a student government that is ideologically balanced over time. A student government, each time it passes a political resolution, takes a position on a highly controversial issue on behalf of all students-even those who dissent or wish to remain silent on the matter. Good, decided before Abood, ignores this line of inquiry, and instead treats student government as one of various other politically active student groups that contribute to a university's forum of ideas. ${ }^{76}$

Second, this policing system would be too difficult to administer. Would three consecutive "liberal" or "progressive" resolutions require three "conservative" resolutions for parity, or would one "moderate" resolution be enough to save the student government? How could a university even begin to categorize the resolutions as "moderate" or "radical" in the first place? A university would be forever subject to lawsuits alleging that its student government had been captured by one ideology.

Under such an approach, courts would either have to ignore Good's rationale and defer to the judgment of a university or routinely entertain legal challenges to student governments. The first possibility would ignore Good's important qualification and the First Amendment values behind it. The second would be unduly burdensome. Hence, Good's solution proves to be no solution at all.

\section{B. The Smith Approach: Funding Is Unconstitutional}

In Smith $v$ Regents of University of California, the California Supreme Court held that the First Amendment prevented the University of California at Berkeley from using mandatory student fees to fund a student senate that passed political resolutions. ${ }^{77}$ As noted above, the Berkeley student senate had passed resolutions on such local, state, and national issues as "gay and lesbian rights, the proposed Equal Rights Amendment, gun control, the reelection of a particular United States Representative, a municipal initiative to legalize marijuana, and the treatment of political prisoners in foreign countries." that the use of their mandatory dues to fund the resolutions

76 Good, 542 P2d at 768-69.

77 16 Cal Rptr 2d at 198.

78 Id at 185. 
violated the First Amendment, appealed from a lower court finding that such funding was constitutional. ${ }^{79}$

Relying primarily on a union dues analogy, the court applied a strict scrutiny test to the university's funding scheme, requiring the state to show that its funding policy was narrowly tailored to serve a compelling state interest. ${ }^{80}$ The court concluded that the value of the educational opportunity afforded students participating in the student senate was clearly outweighed by the First Amendment rights of the plaintiffs and remanded to determine whether student fees had been used. ${ }^{81}$

In dissent, Justice Arabian argued that even if Berkeley used mandatory fees to fund its student senate, its funding scheme would have been constitutional. ${ }^{82}$ Although he found a less demanding legal standard more consistent with Supreme Court precedent, he stated that the university's educational interests were so compelling that he would have reached the same conclusion under the majority's strict scrutiny test. ${ }^{83}$ Justice Arabian found that the funding was "necessarily or reasonably incurred" to effectuate the "important" or "substantial" state interests of exposing students to diverse views and facilitating student debate. ${ }^{84} \mathrm{He}$ concluded that "[s]o long as the university neither seeks by these expenditures to impose a particular ideological orthodoxy nor to stifle intellectual debate, such educational judgments cannot justifiably be questioned." ${ }^{85}$

Smith's analysis was incomplete. First, as Justice Arabian stated, the Smith court's decision to apply a strict scrutiny test does not follow from the Supreme Court case law on which the Smith court relied. ${ }^{86}$ In upholding the imposition of compulsory

79 For a full account of Smith's lengthy procedural history, see id at 185-86.

so Id at 189.

81 Id at 197-98.

82 Id at 199 (Arabian dissenting).

23 Id at $204 \mathrm{n} 3$.

84 Id at 204, quoting Keller, 496 US at 14.

85 16 Cal Rptr $2 d$ at 208 n 6.

86 In determining whether a government regulation passes constitutional muster, the Supreme Court will apply one of three different standards of review. The least probing standard, not at issue here, is called the "mere rationality" or "rational basis" standard. Applying this lowest-level review, the Court will uphold a regulation if it is conceivable that there is some rational relation between the means selected by the legislature and a legitimate legislative objective. See, for example, Massachusetts Board of Retirement $v$ Murgia, 427 US 307 (1976) (link between being over fifty and being physically unfit was not so attenuated as to be irrational, even though better means of measuring health were available). Under this deferential standard, the regulation at issue will almost invariably be upheld. On the other end of the spectrum, the most probing level of review, which 
union dues in Abood, the Court referred to "important government interests" served by the union shop in the system of labor relations established by Congress. ${ }^{87}$ Similarly, in Keller the Court noted that an integrated state bar served "substantial public interests" and held that the expenditure of mandatory dues must be "necessarily or reasonably incurred for the purpose" of effectuating those interests. ${ }^{88}$ Neither decision explicitly applied a strict scrutiny standard. Thus, $S$ mith's reliance on these cases in applying a strict scrutiny test appears misplaced.

Second, the Smith court did not adequately address the educational interests allegedly furthered by funding student governments. Declaring that the education of participating students was the university's sole interest, the court ignored other ways in which political resolutions might serve the university's educational mission. ${ }^{89}$ Had these justifications been identified and considered, the court's conclusion might be more persuasive..$^{90}$

Third, while the court asserted that a less restrictive alternative existed, it based that conclusion solely on its summary conclusion that the present system was too restrictive. ${ }^{91}$ Satisfied with this circular reasoning, the court did not present alternatives that could have provided the same educational benefits without violating First Amendment rights. This Comment pro-

Smith adopts, is "strict scrutiny": a statute will be upheld only if it is found to be necessary (not merely appropriate) to the attainment of a compelling (not merely desirable) governmental objective. See, for example, Loving $v$ Virginia, 388 US 1 (1967) (applying strict scrutiny and striking down a Virginia law prohibiting interracial marriage). As Professor Gunther has said, this level of scrutiny is generally "strict' in theory and fatal in fact," Gerald Gunther, The Supreme Court, 1971 Term: Foreword: In Search of Evolving Doctrine on a Changing Court: A Model for a Newer Equal Protection, 86 Harv L Rev 1, 8 (1972). The Court has also applied an intermediate level of review, between the strict scrutiny and rational basis standards. Under this standard, the Court insists that the regulation at issue "serve important governmental objectives and [ ] be substantially related to achievement of those objectives." Craig $v$ Boren, 429 US 190, 197 (1976) (holding that the fit between the means of regulation selected-the ban on sale of 3.2 percent beer to males between eighteen and twenty years old-and the end sought to be achieved-promotion of traffic safety-was too tenuous to constitute the required "substantial relation" between means and end). The Court used this type of analysis in Abood and Keller.

87431 US at $222,225$.

83 496 US at 13-14

16 Cal Rptr 2d at 207-08 (Arabian dissenting).

so See text accompanying notes 131-33.

9l See 16 Cal Rptr 2d at 193, quoting Carroll, 957 F2d at 999, quoting United States $v$ Albertini, 472 US 675, 689 (1985) ("When mandatory funding is being used to create an incidental benefit to education at the cost of a significant burden on constitutional rights, it cannot usually be said that the state is 'promoting a substantial government interest that would be achieved less effectively absent the regulation."). 
poses a resolution that overcomes the inadequacies of both Good and Smith.

\section{RETHINKING THE CONSTITUTIONALITY OF MANDATORY STUDENT GOVERNMENT FUNDING}

As the Supreme Court has held, the First Amendment does not prohibit all compulsory funding of speech. Abood, Keller, and Lehnert teach that, with respect to unions and state bar associations, a mandatory fee may be used to support political speech as long as the speech is sufficiently related to an important government interest. ${ }^{92}$ This Section demonstrates that these cases provide the proper model for analyzing the mandatory funding of student government political resolutions. The Supreme Court has recognized that the line between activities that are sufficiently related and those that are too attenuated to be constitutionally justified is not always clear. ${ }^{93}$ However, applying the "sufficiently related" test expressed in these cases, this Section concludes that mandatory funding of student government political resolutions often falls within the latter category.

\section{A. The "Sufficiently Related" Test: The Appropriate Analogy}

As noted previously, the Supreme Court has restricted the scope of union political speech that can be constitutionally supported with mandatory funds. In Lehnert, Justice Blackmun concluded that the plaintiffs could not be compelled to subsidize public relations activities because the activities were "not sufficiently related" to the union's collective bargaining function, even though the activities arguably would have enhanced the reputation of the teaching profession and thus would have improved the union's bargaining position. ${ }^{94}$ Blackmun also stated that the union could require dissenters to pay for only those lobbying activi-

\footnotetext{
92 See text accompanying notes $28-45,87-88$.

23 Keller, 496 US at 14-16.
}

Precisely where the line falls between those State Bar activities in which the officials and members of the bar are acting essentially as professional advisors to those ultimately charged with the regulation of the legal profession, on the one hand, and those activities having political or ideological coloration which are not reasonably related to the advancement of such goals, on the other, will not always be easy to discern. But the extreme ends of the spectrum are clear: Compulsory dues may not be expended to endorse or advance a gun control or nuclear weapons freeze initiative.

Id at 15-16.

94500 US at 528-29 (Blackmun opinion). 
ties within "the limited context of contract ratification or implementation. ${ }^{\prime 95}$ Dissenters could not be compelled to subsidize lobbying on other issues, even matters as closely related to the union's interests as taxes for the support of public education. ${ }^{96}$

Likewise, the Supreme Court has restricted the substance of an integrated state bar's political speech that may be constitutionally supported with mandatory funds. In Keller, the Court found that the California State Bar could not compel dues payers to support an annual delegate conference that passed resolutions on such controversial issues as gun control and a nuclear freeze. ${ }^{97}$ In so doing, the Court emphasized that membership in the state bar was based on one's status as a lawyer, not as a voter or citizen; consequently, the bar lacked the representative right to compel funding for its political resolutions. ${ }^{98}$

Under the analysis of Keller and Lehnert, the First Amendment permits public universities to fund speech with mandatory student fees in some circumstances. For example, universities probably may fund ideological and political groups without running afoul of the First Amendment.99 As one commentator explains, "[t]he student fee scenario differs from the Abood model because the universities use mandatory student fees to fund a forum of ideas, not a particular ideology or a group of students that functions as the exclusive mouthpiece of the student body." 100 Unlike unions and integrated state bars, student groups like NOW and the Young Democrats speak only for their members; they in no way publicly implicate nonaffiliated students who disagree with their views. People would not view a student's silence in the face of speech by a political student group as a sign of approbation. In addition, these groups compete on an equal level with all other student groups in a neutral funding allocation system. A university must allocate its mandatory activity fees based on need without regard to the viewpoint of a particular group applying for activity fee funds, ${ }^{101}$ "and therefore

${ }^{95}$ Id at 522 (Blackmun opinion).

96 Id at 527 (Blackmun opinion).

97496 US at 4 . See also note 38.

${ }^{38} 496$ US at 12-13.

59 For a thorough exposition of the issues surrounding ideological and political student groups, see sources cited in note 47.

100 Comment, $55 \mathrm{U}$ Chi L Rev at 373-74 (cited in note 47).

101 See text accompanying notes 71-75. Typically, the university allocates the distribution to a neutral body, often the student council. If a student group thinks that bias has affected its allocation of funds, that group can appeal to the university administration. See Meabon, Alexander, and Hunter, Student Activity Fees (cited in note 4). 
that assessment [to support ideological and political groups] can be "perceived broadly as providing a "forum" for a diverse range of opinion.' $" 102$

Student government political resolutions, however, pose First Amendment problems analogous to those presented by unions and integrated state bar associations. In contrast to the plethora of diverse ideological and political groups that speak only for their voluntary members, student government, like a union that speaks for all employees and an integrated bar that speaks for all a state's lawyers, purports to speak publicly on behalf of all students. As a result, outsiders are far more likely to identify university students with the causes and viewpoints espoused by their student governments' resolutions than with speech by a partisan student group. ${ }^{103}$ Thus, the Good and Smith cases erred in failing to differentiate the constitutional questions presented by student government political resolutions from the questions raised by ideological and political group speech. ${ }^{104}$

One could argue that Congress or a city council presents a more fitting analogy to a state university with respect to its funding of student government political resolutions. According to this argument, because governmental representative institutions can constitutionally pass highly controversial political resolutions over some taxpayers' opposition, so too may a university fund student government political resolutions over the objections of

102 Galda, $772 \mathrm{~F} 2 \mathrm{~d}$ at 1064, quoting its earlier decision reversing summary judgment for the defendants, Galda v Bloustein, $686 \mathrm{~F} 2 \mathrm{~d}$ 159, 166 (3d Cir 1982). See also note 68.

103 Because, in the public mind, students are automatically linked with the positions student governments take on their behalf, a student who would have rather remained silent on the issues addressed by a student government resolution must either accept the repugnant viewpoint as her public stance or voice what may be her own unpopular views, thereby sacrificing her anonymity on the subject. Neither choice is particularly attractive.

With regard to the second choice, Laurence Tribe comments that anonymity has long been recognized as absolutely essential for the survival of dissident movements. "[T]he glare of public disclosure, so healthy in other settings, may operate in the context of protected but unpopular groups as a clarion call to ostracism or worse." Laurence $H$. Tribe, American Constitutional Law $\S 12-26$ at 1019 (Foundation, 2d ed 1988). See also Brown $v$ Socialist Workers '74 Campaign Committee (Ohio), 459 US 87, 91-98 (1982) (holding that disclosure provision of Ohio campaign financing law could not be constitutionally applied to Socialist Workers' Party because First Amendment prohibits compelled disclosure by minor political parties); Talley $v$ California, 362 US 60, 64-65 (1960) (overturning convictions based on an ordinance that banned the distribution of handbills not carrying the name and address of the author, printer, and sponsor); NAACP $v$ Patterson, 357 US 449, 463-65 (1958) (reversing civil contempt judgment against NAACP for refusing to disclose its membership list); Shelton $v$ Tucker, 364 US 479, 487-90 (1960) (invalidating an Arkansas statute requiring each teacher in a state-supported school to file a list of organizations of which they were members or which they actively supported).

104 See note 49 . 
fee-paying students. In both instances, it appears that representative bodies espouse the views of the majority after rational deliberation. ${ }^{105}$ However, based on criteria articulated by the Supreme Court in Keller, a university can be distinguished from these governmental units.

The Supreme Court has recognized that federal and state government officials and agencies "may use unrestricted revenue, whether derived from taxes, dues, fees, tolls, donation, or other sources, for any purposes within [their] authority."106 Congress's decision to pass a resolution condemning apartheid, for example, reflects political decisions in areas specifically delegated to it by the Constitution. All governmental bodies must take substantive positions and decide disputed issues in order to govern. ${ }^{107}$ As the Court has recognized, "[i]f every citizen were to have a right to insist that no one paid by public funds express a view with which he disagreed, debate over issues of great concern to the public would be limited to those in the private sector, and the process of government as we know it radically transformed." ${ }^{2108}$

In Keller, the Supreme Court rejected the view that an integrated bar association, while providing valuable public services to the state in regulating the legal profession, could be equated to a governmental body. The Court rested this judgment on two principal distinctions. First, the Court noted that the California State Bar, unlike lawmaking institutions, serves merely an advisory role and is not involved in the direct governance of the state. ${ }^{109}$ Second, it recognized that the bar's members are members because they are lawyers, not because they are citizens or voters. ${ }^{110}$ Consequently, the bar lacks the general representative right that a government body enjoys. ${ }^{111}$ The Court therefore found that the bar's use of compulsory dues was subject to the

\footnotetext{
105 For a thorough exposition of the position that state bar associations, labor unions, and public universities are analogous to governmental bodies, see Cantor, 36 Rutgers $L$ Rev at 39-52 (cited in note 47) (reviewing implications of typical forced payment arrangements).

${ }^{106}$ Keller, 496 US at 9, quoting Keller $v$ State Bar of California, 47 Cal 3d 1152, 255 Cal Rptr 542, 551 (1989).

${ }_{107}$ Keller, 496 US at 9. Government may speak despite citizen disagreement with the content of its message, for the government is not required to be neutral. Id.

${ }^{108}$ Id at 12-13. Compare United States $v$ Lee, 455 US 252, 260 (1982) ("The tax system could not function if denominations were allowed to challenge the tax system because tax payments were spent in a manner that violates their religious belief.").

${ }^{109} 496$ US at 11.

10 Id at 12.

111 Id at 12-13.
} 
same constitutional rule as a labor union's use of similar dues. ${ }^{112}$

The considerations that moved the Court in Keller to find that integrated state bars are better analogized to labor unions than to lawmaking bodies are equally applicable to student governments. First, a state university, while undoubtedly serving substantial public interests, is created not to participate in the direct governance of the state, but rather to educate. Student government political resolutions, like the delegate conference's resolutions in Keller, are merely "advisory" both to the university administration in setting university policy and to the lawmaking institutions that actually do govern. Second, "the reason for permitting the government . . . to spend [tax] money on controversial projects is that the government is representative of the people."113 However, like the lawyers in Keller, whom the bar represented in only their professional capacity, students attend a university primarily for an education, not to participate as citizens or voters. These differences demonstrate that a public university, with respect to its funding of student government political resolutions, is better analogized to a labor union or an integrated bar than to a lawmaking institution.

\section{B. Applying the "Sufficiently Related" Test}

Student government political resolutions impose the same constitutional burden on dissenters as the state bar's resolutions in Keller. There, the Court held that the delegate conference's resolutions were unconstitutional because they were not sufficiently related to the California Bar's function of "acting essentially as professional advisers to those ultimately charged with the regulation of the legal profession."114 Thus, whether a university may constitutionally use mandatory student fees to fund student government political resolutions should depend on whether the student government resolutions in question are sufficiently related to the university's educational mission.

Most student government political resolutions are not sufficiently related to a university's educational mission to justify the First Amendment burden resulting from compulsory funding. In order to be "sufficiently related," they must directly concern university and student affairs. ${ }^{115}$ Instead, political resolutions often

\footnotetext{
112 Id at 12.

113 Id at 11, quoting Abood, 431 US at 259 n 13 (Powell concurring).

114496 US at 15.

115 For example, in discussing the ideological lobbying activities of a political advocacy
} 
range beyond the purview of student affairs and address topics about which students hold strong personal views outside of their capacity as students. One would expect these views to be highly diverse, given that students represent a broad spectrum of values, philosophies, and cultures whose sole common objective is often participation in the educative process. As Justice Blackmun indicated in Lehnert, "[w]here the subject of compelled speech is the discussion of governmental affairs, which is at the core of our First Amendment freedoms, the burden upon dissenters' rights extends far beyond the acceptance of the agency shop and is constitutionally impermissible."116 A university thus may not fund student government political resolutions that are highly public, controversial, and outside the scope of student affairs. ${ }^{17}$

Under this analysis, a university is not altogether forbidden from funding some student government resolutions. But, as in the case of integrated state bars and labor unions, the line between student government activities germane to the university's educative function and those lacking a sufficiently strong con-

group, the Galda court noted that the subject matter of the lobbying at issue was an additional factor which burdened students' rights. $772 \mathrm{~F} 2 \mathrm{~d}$ at 1065 . While matters such as a nuclear freeze initiative "may affect the general public, those causes are not particularly germane to students of the University qua students." Id.

116500 US at 522 (Blackmun opinion) (citations omitted). Student governments do indeed aim at a large and important public audience. Their resolutions are often widely publicized in major newspapers, see Section $I$, in leaflets, on flyers, in informational books, in letters to local, state and national officials, and in televised rallies. See, for example, Smith, 16 Cal Rptr 2d at 198 (discussing the methods that Berkeley's student senate used to publicize their resolutions). Student governments thus target audiences outside the university community, whether it be the voting public, the news media, the United States military, local and state legislatures, Congress, or the President. As Justice Blackmun has noted, "[t]he burden upon freedom of expression is particularly great where ... the compelled speech is in a public context." Lehnert, 500 US at 522 (Blackmun opinion).

117 Note that this analysis would not change if a university were to fund a student government that passed political resolutions with money derived from other sources, such as directly from the administration, the bookstore, or other concessions, while "segregating" the mandatory fees for other, nonpolitical purposes. In Abood, the Court rejected such earmarking as a remedy for constitutional violations caused by the use of mandatory fees for political purposes. Because earmarking leaves the same total amount of funds at the organization's disposal and permits the organization to spend the same amount on political activities, earmarking "is of bookkeeping significance only rather than a matter of real substance." Abood, 431 US at 237 n 35, quoting Retail Clerks Local 1625 v Schermerhorn, 373 US 746, 753 (1963). For these reasons, the Court has held in the agency-shop context that "[i]t is plainly not an adequate remedy to limit the use of the actual dollars collected from dissenting employees to collective-bargaining [nonpolitical and nonideological] purposes." Abood, 431 US at $237 \mathrm{n} 35$. Similarly, a university cannot solve the constitutional problems associated with funding student governments that pass political resolutions simply by creating such artificial allocative distinctions. 
nection will not always be easy to draw. ${ }^{118}$ Some student government resolutions will involve highly controversial topics that also relate to student affairs.

For example, student governments have passed resolutions demanding that the ROTC be ejected from campus because of the U.S. Military's ban on homosexuals. ${ }^{119}$ Admittedly, such a resolution does involve a highly controversial subject of public policy, that is, the role that sexual orientation should play in society. However, it also relates directly to student affairs: many students' career plans and tuition payments hinge directly on their participation in the ROTC. University administrators must fashion the policies and regulations by which the university is to be governed. In order for these policies to be effective, the input of the student body is both desirable and necessary. The university's interest in maintaining contact with the student body, together with the students' interest in conveying their concerns about campus affairs to the university administration via their representatives, probably makes such resolutions "sufficiently related" to justify university funding.

Given the extremely broad nature of a public university's educational mission, all student government political resolutions, even if not related to student affairs, probably have some value to university interests. However, merely because a student government resolution might serve the university's interest in educating its students and promoting debate in some remote way does not make it automatically "sufficiently related" to pass First Amendment muster.

If a university's funding decisions were always constitutional provided that they served the university's educational mission in any manner, students' First Amendment protections would be subject to the discretion of a university's administration. First Amendment rights would effectively assume a secondary status in the university context. But the Supreme Court has consistently rejected the subordination of First Amendment rights to university policy, declaring that "the precedents of this Court leave no room for the view that... First Amendment protections should apply with less force on college campuses than in the community at large. Quite to the contrary, '[t]he vigilant protection of constitutional freedoms is nowhere more vital than in the community of American schools." ${ }^{\prime 120}$

118 See note 93 .

119 See text accompanying notes 9-10.

120 Healy $v$ James, 408 US 169, 180 (1972), quoting Shelton $v$ Tucker, 364 US 479, 487 
In determining whether a student government resolution is sufficiently related to university interests, a court should construe such interests narrowly. Indeed, in the analogous context of an integrated state bar, the Supreme Court has implied that it will define an institution's interests restrictively in determining whether compelled funding is justified. The California Bar's resolutions that the Court struck down in Keller arguably educated participating lawyers and promoted debate within the legal community about the law's treatment of controversial social issues, vital components of the bar's self-defined function. Indeed, the American Bar Association ("ABA") Model Code of Professional Responsibility recognizes that lawyers, "[b]y reason of education and experience, ... are especially qualified to recognize deficiencies in the legal system and to initiate corrective measures therein." ${ }^{121}$ Accordingly, the ABA mandates that a lawyer should "do his part individually and as a member of an organized bar to improve his profession, the courts and the law."122 The ABA specifically charges lawyers with the duty to work toward the repeal of outmoded laws and the passage of those to serve the public interest. ${ }^{123}$

Nevertheless, the Supreme Court held that the resolutions on gun control and nuclear weapons were not sufficiently related to the California Bar's mission to justify the burden on

(1960). Furthermore, the Galda court recognized that the concerns of labor unions and universities differ, "particularly in light of the [university's] traditional interest in presenting and discussing differing philosophies and theories on a wide range of topics"; nevertheless, the court declared that "[t]he relevance of Abood, however, is not lost" in the university setting. $772 \mathrm{~F} 2 \mathrm{~d}$ at 1067.

${ }^{121}$ Model Code of Professional Responsibility EC 8-1 (1980). The ABA further directs lawyers that "[a]s a public citizen, a lawyer should seek improvement of the law .... As a member of a learned profession, a lawyer should cultivate knowledge of the law beyond its use for clients [and] employ that knowledge in reform of the law .... A lawyer should aid the legal profession in pursuing these objectives and should help the bar regulate itself in the public interest." Model Rules of Professional Conduct Preamble If 5 (1994).

122 Model Code of Professional Responsibility EC 8-1 n 1, quoting Arthur T. Vanderbilt, The Five Functions of the Lawyer: Service to Clients and the Public, $40 \mathrm{ABA} J$ 31, 31 (1954).

${ }^{123}$ The Model Code of Professional Responsibility states that:

Rules of law are deficient if they are not just, understandable, and responsive to the needs of society. If a lawyer believes that the existence or absence of a rule of law, substantive or procedural, causes or contributes to an unjust result, he should endeavor by lawful means to obtain appropriate changes in the law. He should encourage the simplification of laws and the repeal or amendment of laws that are outmoded.

Model Code of Professional Responsibility EC 8-2 (1980). 
dissenters' First Amendment rights. ${ }^{124}$ Thus, in applying the "sufficiently related" test in Keller, the Court defined the scope of the bar's interests narrowly, even though the range of the bar's actual functions is much broader. ${ }^{125}$

Furthermore, in accordance with these restrictive parameters that the Court has placed around the "sufficiently related" criterion, the Court in Lehnert indicated that a union's funding of political resolutions must be carefully tailored to serve its interests without undue infringement on First Amendment rights. ${ }^{126}$ Thus, where a university has other, less intrusive ways of achieving its goals, funding political resolutions that pose a significant First Amendment burden should not be constitutionally permissible. ${ }^{127}$ No one can doubt the legitimacy of a public university's interest in educating participating students and encouraging debate within the student body. ${ }^{128}$ State universities encourage the development of student extracurricular life to supplement learning in the classroom. ${ }^{129}$ Yet, even when the university has

${ }^{124}$ Keller, 496 US at 16.

125 Id at 15-16.

${ }_{225} 500$ US at 518. The Lehnert Court held that in order to be constitutional an expenditure cannot "significantly add" to the First Amendment burden of compelling all workers to pay dues to the union that represents them. Id at 519.

${ }^{127}$ Even partisan-student-group cases have recognized the importance of this principle. The Carroll court, which required a "substantial government interest that would be achieved less effectively absent the regulation," required that the university regulation be "narrowly drawn to avoid unnecessary intrusion on freedom of expression." 957 F2d at 999 (quoting United States v Albertini, 472 US 675, 689 (1985); Schad v Mount Ephraim, 452 US 61,69 n 7 (1981)). Also, while expressly adopting the principles in Abood, the Galda court held that a state regulation "unnecessarily restrict[s] constitutionally protected liberty, [when] there is open a less drastic way of satisfying its legitimate interest." 772 F2d at 1066.

${ }^{128}$ See Alabama Student Party $v$ Student Government Ass'n of University of Alabama, 867 F2d 1344, 1347 (11th Cir 1989), where the court noted that the university viewed its student government association as a "learning laboratory" through which students who are interested in pursuing a career in the public sphere may gain experience in the democratic political process. The court noted that "[s]tudent government . . . constitute[s] a forum reserved for its intended purpose, a supervised learning experience for students interested in politics and government." Id.

The Supreme Court has recognized that the free exchange of ideas at public universities is critical to the survival of our democratic institutions. "The Nation's future depends upon leaders trained through wide exposure to that robust exchange of ideas which discovers truth 'out of a multitude of tongues, [rather] than through any kind of authoritative selection." Keyishian $v$ Board of Regents of University of State of New York, 385 US 589, 603 (1967), quoting United States v Associated Press, 52 F Supp 362, 372 (S D NY 1943), aff'd, 326 US 1 (1944). "Teachers and students must always remain free to inquire, to study and to evaluate, to gain new maturity and understanding; otherwise our civilization will stagnate and die." Sweezy v New Hampshire, 354 US 234, 250 (1957).

${ }^{22}$ See, for example, Widmar $v$ Vincent, 454 US 263, 279 n 2 (1981) (Extracurricular activities are "critical aspect[s] of campus life."); Carroll, 957 F2d at 999-1000 (stressing 
a sufficiently compelling interest to require a person to subsidize an organization against his or her will, the resulting burden on freedom of speech "requires that the regulation be carefully tailored to minimize the infringement."130

A university can pursue its educational interests in other ways that do not compel students to financially contribute to a student government that passes political resolutions with which they disagree. ${ }^{131}$ First, a university could avoid First Amendment problems and still educate students participating in student government by maintaining a student government that did not pass political resolutions. Student governments are responsible for allocating the student budget and communicating student concerns to the university administration. Participants could learn from managing these student-related activities, which have traditionally constituted the majority of student government business and remain a proper function for an entity purporting to represent all the students in their capacity as students.

Participating students might still be able to pass resolutions closely tied to student affairs. In Keller, while the California Bar

the educative value of participating in a range of extracurricular activities); Veed $v$ Schwartzkopf, 353 F Supp 149, 152 (D Neb 1973), aff'd, 478 F2d 1407 (8th Cir 1973) (reasoning that extracurricular groups are as much a part of the educational process as are classroom teachings).

130 Chicago Teachers Union, Local No. 1 v Hudson, 475 US 292, 303 (1986) (striking down a union's constitutional safeguards as inadequate). In Hudson, the Supreme Court reiterated Abood's message that "[i]nfringements on freedom of association 'may be justified by regulations adopted to serve compelling state interests, unrelated to the suppression of ideas, that cannot be achieved through means significantly less restrictive of associational freedoms." Id at $303 \mathrm{n}$ 11, quoting Roberts $v$ United States Jaycees, 468 US 609, 623 (1984).

${ }^{231}$ It is unlikely that a university can escape the limitations of the First Amendment by simply offering objecting students a refund upon request. While the Abood Court explicitly refrained from addressing the question of whether a refund mechanism is suffcient to render constitutional a fee collection and expenditure, 431 US at $242 \mathrm{n} 45$, the Supreme Court later explicitly recognized that "a rebate approach" is inadequate because dissenters' funds were used even temporarily for causes they opposed. Hudson, 475 US at 309-10 (striking down a union's rebate procedure as inadequate). See also Keller, 496 US at 17 (explicitly adopting Hudson in the integrated bar setting). Thus, state bars and unions cannot use a member's dues even temporarily for impermissible purposes.

Similarly, a system in which a university would refund objecting students' fees after a political resolution is passed and publicized seems equally problematic. Both courts and commentators have generally rejected the proposition that a student-fee refund mechanism could remedy a potentially unconstitutional fee allocation. See Note, 15 Rutgers L J at 178-79 (cited in note 47); Comment, $11 \mathrm{~J}$ Coll \& Univ L at 495-99 (cited in note 47). As one court noted, "even a temporary exaction of the [] fee . . . cannot be [constitutionally] justified...." Galda v Bloustein, 686 F2d 159, 169 n 18 (3d Cir 1982). "[A] funding system requiring continual payments and subsequent refunds to dissenters may not satisfy the requirements of the first amendment." Id at 168. 
could not constitutionally fund resolutions on controversial political issues, the Court was equally adamant that bar members would have no constitutional objection to resolutions disciplining bar members or recommending a code of ethics for the legal profession. ${ }^{132}$ Likewise, student governments could presumably debate and pass resolutions on such important student affairs as tuition levels, financial aid, and academic programming. Such resolutions, within the scope of an assembly elected to represent the student body to the administration, could give participating students the valuable educative experience universities seek to provide through the student government without violating First Amendment rights.

Second, students could gain the same educational experience by joining student debating societies, whose core purpose is debating and passing resolutions on important public issues. Participation in such a group would afford a student all of the educational benefits he would have received from doing the exact same activity in student government.

Third, nearly all public universities currently fund many political student groups with widely divergent viewpoints and ideologies, thereby promoting an atmosphere of vigorous public debate in which individual students may voice their political views. ${ }^{133}$ While ideological and political student groups provide just as effective a medium for students to express themselves, these groups do not purport to be, and would not be viewed as, the official voice of all students. This insures that no speech will be excluded, that debate will flourish, that all who want to contribute to the controversy on an issue will be able to speak for themselves, and that all those who wish to remain silent can do so without forfeiture of their First Amendment rights.

\section{CONCLUSION}

This Comment has shown that student government political resolutions impose a substantial burden on the First Amendment rights of students who either disagree with the position taken in a particular resolution or who wish to remain silent on the issue.

132496 US at 16.

${ }^{133}$ The notable exceptions are the University of California campuses. See text accompanying notes 57-61. No other court before or since the California Supreme Court's ruling in Smith has prohibited a public university from funding political or ideological student groups generally. Indeed, courts have been nearly unanimous in their rejection of such constitutional challenges. See note 48 . 
Because these highly public, controversial student government resolutions purport to speak on behalf of all the students, universities may not constitutionally use mandatory student fees to fund them unless they are sufficiently related to the university's educational interests. In determining whether a student government resolution is sufficiently related to university interests, a court should construe these interests narrowly as well as consider whether the university has other, less intrusive means by which to achieve its interests.

In most cases, restricting a university from funding student government political resolutions will not impair the university's educational commitment. Often a university easily can both educate participating students and maintain an atmosphere conducive to debate and controversy without imposing a burden on dissenting students. By not funding political resolutions, a university would lose few educational benefits while still protecting students' First Amendment rights. Courts should look favorably on such a compromise, where everyone benefits and little is sacrificed. 
